YAK 347.97/.99

ББК 67.71

DOI 10.22394/1682-2358-2018-2-65-70

A.K. Tikbonov, Candidate of Sciences (Law), Docent of the Social and Legal Sciences, Humanities and Pedagogies Department, Saratov State Agrarian University named after N.I. Vavilov

\section{EDUCATIONAL \\ ROLE OF THE COURT}

The article examines various aspects aimed at improving the educational impact of the court not only on the participants of the court session, but also on all citizens of our country. It is proved that the current legislation of Russia generally enhances the educational role of court sessions, as well as their authority. Directions of strengthening the educational role of the court are analyzed.

Key words and word-combinations: justice, judicial authority, criminal proceedings, safety of the victim, the rights and legitimate interests, change in charges.
А.К. Тихонов, кандидат юоридиеских наук, дочент кафедрь сочиально-правовьхх и гуманитарно-педагогиеских наук Саратовского государственного аграрного университета имени Н.И. Вавилова

(email: tikbonovsar64@gmall.com)

\section{ВОСПИТАТЕАЬНАЯ РО $\triangle \mathrm{b}$ СУАА}

Аннотация. Рассматриваются различные аспекты повышения воспитательного воздействия суда на граждан. Доказывается, что действующее законодательство России в целом способствует повышению воспитательной роли судебных заседаний, а равно их авторитета. Анализируются направления усиления воспитательной роли суда.

Ключевые слова и словосочетания: правосудие, судебная инстанция, уголовное судопроизводство, безопасность потерпевшего, права и законные интересы, изменение обвинения.

C удья,, возглавмяющий судебное засеАание, не только им руководит, принимая меры к выяснению всех подлежащих Аоказыванию обстоятельств Аела, но и обеспечивает воспитательное воздействие судебного заседания [1]. Воспитательный эффект суАебного процесса зависит и от уровня его организации, и от культуры самого судьи. Здесь нет мелочей. Так, несвоевременное начало сулебного заседания, отсутствие списков подмежкащи слушанию дем и иные факты серьезно подрывают авторитет не только конкретного судебного засеАания, но и всей судебной системы. Подобные «мелочи» нереАко приводят к срыву судебных засеАаний и Аругим отрицательным последствиям. 
На это обстоятельство специально неоднократно обращалось внимание высшими судебными органами страны. Так, еше 7 февраля 1967 г. Пиенум Верховного Суда РСФСР принял постановление № 35 «Об улучшении организации судебных процессов и повышении культуры их проведения» [2]. В это постановление вносились изменения и дополнения постановлениями Пиенума российского Верховного Суда от 20 декабря 1983 г. № 10, от 21 декабря 1993 г. № 11, от 25 октября 1996 г. № 10, от 6 февраля 2007 г. № 5.

Безусловно, Аюбая деятельность требует домжной организаџии в Аюбом российском государственном и муниципальном учреждении, в суде же такая организаџия должна быть образџовой. Аишь тогда у судей будет нравственная возможность судить других за нарушение законов, в том числе и за преступления [3]. ОАним из основных требований, предъявляемых к судебному заседанию, явмяется неукоснительное соблюдение закона как самим судьей (судом), так и всеми участниками проџесса. Аюбое, Ааже на первый взгляд незначительное отступление от закона, недопустимо, ибо оно сводит на нет воспитательное воздействие решения суда $[4 ; 5]$.

Соблюдение законности судьей (судом) должно проявцяться буквально во всем: в объективности рассмотрения дел, внимательном отношении к участникам судебного разбирательства, в постановке вопросов допрашиваемым миџам, поддержании порядка в зале заседания и, естественно, в правильности и справедливости принятого решения [6; 7]. Если судья (суА) рассматривает дело в явно обвинительном плане, необоснованно отклоняет заявленные по существу ходатайства защиты, удовлетворяя в то же время ходатайства обвинения, то у гражАан, сидящих в зале, может невольно возникнуть сомнение в беспристрастности председательствуюшего в засеАании. Это касается и рассмотрения дел с участием присяжных, когда судья склоняет их в сторону обвинения.

К сожалению, в юридической митературе мало внимания обрашается на так называемый защитительный уклон судебного разбирательства [8]. Мотивируется это презумпџией невиновности, правом обвиняемого на защиту, толкованием всех сомнений в пользу подозреваемого, обвиняемого, подсудимого и Аругими уголовно-проџессуальными принџипами. ОАнако судья (суА), вынося мюбое решение по уголовному делу, Аолжен руководствоваться не только этими и Аругими принципами, стоящими на защите прав и законных интересов $и$ п, привлекаемых к уголовной ответственности, но и защищать интересы потерпевших от преступлений, что является первоочередным назначением уголовного судопроизводства (ст. 6 УПК РФ).

Например, коммегиальное решение суда, оџенившего при пересмотре в порядке надзора вероятное заключение почерковедческой экспертизы в пользу осужденного, признав такое заключение оправдательным доказательством, становится формально справедливым. Ведь все сомнения должны толковаться в пользу осужденного (подозреваемого, обвиняемого, подсудимого). Отменяя обвинительный приговор по этому делу, надзорная инстанция положила в основу своего оправдательного определения именно это экспертное заключение. При этом она безмотивно отвергла показания свидетелей, которые подтвержАаАи, что подпись (по поводу которой производилась почерковеАческая экспертиза) была поставлена исполнены осужденным в их присутствии. 
Впоследствии ни в судебном разбирательстве, ни в кассационном и надзорном рассмотрении эти показания не быми опровергнуты. Такая необъективная позиџия суда, проявмяющаяся в конкретном деле, дискредитирует судебную систему, ослабляет веру мюдей в справедливый и объективный суд.

В судебной практике имеются случаи, когда подобное рассмотрение дела приводит к заявлению отвода состава суда, что, в свою очередь, создает напряженную обстановку, уводя суА от существа рассматриваемого вопроса, заставмяя заниматься не поисками истины, а урегулированием процедурных конфциктов. Подавцяющее большинство дел в судах рассматривается в открытых судебных заседаниях, где присутствуют многие граждане. Еще и поэтому суду важно проявлять выдержкку и терпение, доброжелательное и чуткое отношение ко всем участникам судебного заседания, строго придерживаться установценного законом порядка исследования доказательств. Строгое соблюдение судебной этики имеет огромное воспитательное значение.

Вопрос об авторитете суда и принимаемых им решения - важная составцяюшая проблемы повышения эффективности правосудия, что тесто взаимосвязано с воспитательной ролью судебной системы. Каждый промах в этой сфере деятельности отдельного судьи подрывает значение всей системы в цецом и ведет к снижению воспитательной роли суда в частности. В последние годы многое сделано по совершенствованию правосудия, созданию надмежаших условий Аля работы судов и улучшению кадров судебных работников. Опора судей на Конституџию РФ, имеюшей прямое действие, в своей непосредственной деятельности (особенно в случаях, когда правовые нормы вступают с ней в комлизию) также способствует повышению правоохранительной и воспитательной роли суда, а равно и его авторитета.

Вместе с тем высокие требования, предъявляемые к судьям в современных условиях, обусловливают необходимость дальнейшего повышения доверия и уважения к суду. Не касаясь всех аспектов этой многогранной проблемы, остановимся на некоторых вопросах воспитательной роли суда. Аостойно выполнять обязанности, возмагаемые на судебные органы, могут мишь те, у кого профессиональные знания сочетаются с неподкупностью и справедливостью.

Представляется что в џемях повышения воспитательной роли суда и, следовательно, эффективности правосудия уголовно-проџессуальное законодательство и его правоприменительная практика нуждаются в расширении прав суда и повышении авторитета судебной системы. Учитывая, что в суде существуют самые большие возможности Аля познания истины и справеАливого разрешения дела при строгом соблюдении прав обвиняемого на защиту желательно наделить суА первой инстанџии несколько большими правами и обязанностями:

a) на изменение обвинения;

б) на обеспечение прав и законных интересов потерпевшего от преступления (в частности, при вынесении таких решений в отношении обвиняемого (подозреваемого или подсудимого), как отказ в даче согласия на заключение поА стражу или продление срока содержания его под стражей; переквалификаџия преступного деяние на менее тяжкое; прекращение дела в связи с истечением срока Аавности и т.п.); 
в) на обеспечение безопасности потерпевших, а равно свидетелей. Именно эта категория участников уголовного судопроизводства чаще всего подвергается противоправному воздействию с џелью повАиять на их позиџию в судопроизводстве [9]. Неспособность судей своевременно и на достаточном уровне обоснованности обеспечить их защиту существенно снижает воспитательное значение судебной деятельности;

г) на применение необходимых мер воздействия к мицам, противодействующим нормальному осуществлению правосудия [10, с. 41] .

На наш взгляА, право российского суда на изменение обвинения сформумировано узко и поставлено в чрезмерную зависимость от материалов и выводов органов предварительного расследования. Это приводит в ряде случаев к формально обоснованному в отношении обвиняемого (подозреаемого ици подсудимого) судебному решению. ОАнако если спроецировать его на права и законные интересы потерпевшего, то по существу это будет издевательство наА послеАним. ПреАставляется, что значительно поАнимется воспитательная роль суда, если законодатель не только продекларирует защиту прав и законных интересов киџ и организаџий, потерпевших от преступлений (ст. 6 УПК РФ), но и предаст им равноценный проџессуальный статус с обвиняемым. Аیя этого смедует нормативно закрепить обязанность государства возместить материальный ущерб от преступления потерпевшему и кишь затем взыскивать эти материальные затраты с виновного в преступлении [11, с. 26]. Такая позиџия законодателя также повысит воспитательное значение суда.

Кроме того, правоприменительная практика настоятельно требует восста-

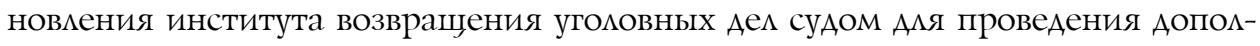
нительного расследования. Ведь пределы судебного разбирательства Аля стороны обвинения и, соответственно, Аля суда ограничены объемом обвинения, предъявленного органами предварительного расследования. ОАнако возможность увеличения данного объема в рамках судебного разбирательства категорически отвергается на основании российского уголовного судопроизводства. Это означает, что еще до судебного разбирательства следователь или дознаватель «предопределяют» его ход, поэтому в проџессе расследования деяние нередко квалифицируется с «запасом». Например, при очевидных грабительских действиях Аиџо привлекается к ответственности за разбойное нападение. Из материалов же дела усматривается, что умысел обвиняемого был направлен на открытое похишение имушества без применения насилия или его угрозы.

Подобное положение правоприменения отриџательно сказывается на воспитательной роли суда. Вместе с тем декларативно собирание доказательств на предварительном расследовании не завершается. В судебном разбирательстве и сторона обвинения, и сторона зашиты вправе получить и представить в суде новые доказательства, позволяющие установить факт обвинения гораздо большего или меньшего объема, чем это бымо установлено при расследовании. Такая процедура изменения обвинения никакой пользы правосудию не приносит. Она явно не соответствует роли суда вершить правосудие, снижает его авторитет и воспитательную роль. Обычно в юридической китературе подобные ограничения оправдываются необходимостью обеспечения права обвиняемого 
на защиту. Этот уголовно-процессуальный принщип подмежит безусловному обеспечению, но это можно сделать более раџионально. Например, предоставить подсудимому возможность как самому мично, так и с помощью адвоката осуществлять свою защиту в суде с учетом изменений, внесенных в обвинение. Кстати, рациональность и справедмивость такой процедуры подтверждена законодательным опытом многих государств - Индии, Чехии, Словакии и Аругих.

По нашему мнению, недостаточны и права суда на применение мер возАействия против Аиџ, мешающих осуществлению правосудия. Нередко встречаются факты неявки или несвоевременной явки свидетелей в суд. Это влечет задержки в рассмотрении дел или отможение их рассмотрения, иногда неоднократно. Это не только дезорганизует работу суда, но и отриџательно сказывается на его воспитательном значении, снижает эффективность судебных проџессов. При этом впустую тратятся государственные средства, рабочее время Аиц, вызываемых в суд.

Представляется, что правомерным противодействием таким ситуациям будет предоставление судье (суду) права при неявке свидетелей без уважительных причин взыскивать с них издержки судопроизводства, которые возникли по их вине. Следует усилить также правомерное противодействие таким явным проявлениям неуважения к суду, как мжесвидетельство. Распространенная безнаказанность этого преступмения против правосудия снижает воспитательное значение судебной деятельности. Судья (суА) при бесспорном установлении в судебном заседании факта мжесвидетельства должен иметь возможность подвергать мжесвидетеля наказанию без направления дела на предварительное расследование. Воспитательное воздействие суда при реализаџии такого преАложения будет бесспорным.

Воспитательное воздействие суда снижается и в тех случаях, когда государственные и муниципальные должностные миџа игнорируют решения, принятые в суде, препятствуют их исполнению. Факты неуважения к суду и беспомощности суда при неисполнении его решений достаточно распространенные, поэтому считаем целесообразным дополнить главу 31 Уголовного кодекса РФ «Преступления против правосудия» статьей, предусматривающей ответственность за умышиенное неисполнение принятых судом решений [12] .

Не способствует повышению воспитательной роли суда и неоднократный пересмотр приговоров и иных решений в порядке надзора. Необходимо проанализировать правовые гарантии устойчивости и непоколебимости таких приговоров и иных решений. В интересах укрепления стабильности приговора его пересмотр в надзорном порядке следует допускать только один раз. Сегодня же в зависимости от того, суА какого уровня рассматривал дело по первой инстанции, зависит и количество возможностей подать наАзорные жамобы. Это уже само по себе ставит в разные правовые условия участников судопроизводства, имеющих свои законный интерес в уголовном деле.

Если же и после надзорного решения обнаруживается незаконность и необоснованность приговора, то в таком случае может быть использован существуюший институт пересмотра по вновь открывшимся обстоятельствам приговоров и иных судебных решений, вступивших в законную силу. Отметим, что 
во многих государствах это явмяется единственным институтом пересмотра приговоров, вступивших в сицу [13] .

Воспитательное воздействие судебной системы, несомненно, повысится при

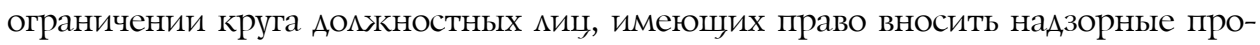
тесты. Следует отказаться от существуюшего парамлекизма, то есть от возможности вносить надзорные протесты не только прокурорам, но и преАседателям судов. Опротестование приговоров в надзорном порядке должно быть функщией только прокуроров, которые согласно Конституции РФ осуществляют высший надзор за соблюдением законности в государстве. Судьи же в соответствии с их

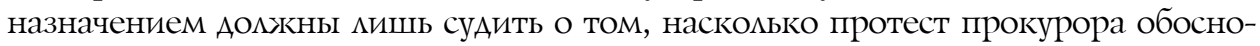
ван и принимать решение по существу дела. Это исключит существующее ныне фактическое смешение функщий прокурорского надзора и функщий суда.

Воспитательная роль суда повысится, если отношение председательствующего в судебном заседании судьи ко всем его участникам будет базироваться на уважении человеческого достоинства, искренней заботе о человеке. Этот принцип, составляющий основу этико-правовой деятельности суда, еАин по отношению ко всем участвующим в заседании и со стороны обвинения, и со

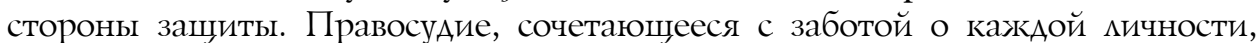
оказавшейся в сфере судопроизводства, с защитой ее прав и законных интересов, всегда имеет положительное воспитательное воздействие.

\section{Библиографический список}

1. Уголовно-процессуальный кодекс Российской Федерации от 18 декабря 2001 г. № 174-Ф3. M., 2018.

2. Бюллетень Верховного Суда СССР. 1967. № 2. С. 9-14.

3. О государственной защите судей, должностных лиц правоохранительных и контролирующих органов: Федер. закон от 20 апр. 1995 г. № 45-Ф3. М., 2016. URL: http://base.garant. $\mathrm{ru} / 10104593 /$

4. О государственной защите потерпевших, свидетелей и иных участников уголовного судопроизводства: Федер. закон от 20 авг. 2004 г. № 119-Ф3. М., 2018. URL: http://base.garant. $\mathrm{ru} / 12136633 /$

5. Рагинский М.Ю. Воспитательная роль советского суда. По уголовным делам. М., 1959.

6. Ориент M. Фемида и общественное сознание (о воспитательной функции суда: история и современность). URL: http://pandia.ru/text/80/465/10232.php

7. Тулаева Ю.В. Из истории: о воспитательной функции суда. URL: http://poronaiskiy. sah.sudrf.ru/modules.php?name=press_dep\&op $=4 \&$ did $=10$

8. Качалова О.В. Функции суда в современном российском уголовном судопроизводстве // Российский судья. 2014. № 1. С. 8-10.

9. Голяков И.Т. Воспитательная роль суда // Социалистическая законность. 1945. № 3 (март). С. 1-11; № 4 (апрель). С. 31-43

10. Аминов И.И. [и др.] Нравственная составляющая воспитательной деятельности судов в советский и постсоветский периоды // Юридическая этика: учебное пособие. М.. 2012.

11. Тихонов А.К. Потерпевший: Уголовно-процессуальный аспект // Советская юстиция. 1993. № 19.

12. Уголовный кодекс Российской Федерации от 13 июня 1996 г. № 63-ФЗ (в ред. от 23 апр. 2018 г.). URL: http://www.consultant.ru/document/cons_doc_LAW_10699/

13. Шишов Е.A. К вопросу о воспитательной функции судебного решения // Аспирантский вестник Поволжья. 2014. № 7/8. С. 107-111. 